\title{
Uber as For-Profit Hiring Hall: A Price-Fixing Paradox and its Implications
}

\author{
Sanjukta M. Paul ${ }^{\dagger}$
}

If the members of a hiring hall, run by a labor union or directly by workers, were deemed independent contractor service providers, it and they would be engaging in impermissible price-fixing under the conventional interpretation of antitrust law. Yet Uber has thus far been permitted to engage in precisely this sort of price coordination between workers it claims are independent contractors-for its own economic benefit, rather than workers'. Uber is operating a virtual, for-profit hiring hall, and it is doing so on terms that would not be allowed to workers themselves. It has thus far been permitted to do this simply because it is organized as a business firm. However, Uber's model pushes against the limits of intra-firm immunity from price-fixing liability, which has long been an unwritten assumption of antitrust law, and it reveals how a firm's relationship to workers interacts with the justifications for this assumption. It also forces us to confront the underlying justifications for what this paper calls the firm exemption. In particular, this paper shows that in a contemporary service economy that increasingly relies upon work performed outside the bounds of the employment relationship, the firm exemption leads to a regulatory inconsistency. This internal inconsistency can be remedied by permitting service providers, such as Uber drivers, to engage in collective action in their bargains with the firm that sets prices in the services they perform, whether or not they are legally employees. This paper thus furnishes an argument in favor of collective bargaining rights that relies neither upon workers' status as employees nor upon independent reasons in favor of collective bargaining, but rather upon a simple principle of consistency in

DOI: https://dx.doi.org/10.15779/Z382V2C89G

$\dagger \quad$ I am grateful to Noah Zatz, Kathy Stone, Cynthia Estlund, Amy Sepinwall, Sanford Jacoby, and Charlotte Garden for their valuable feedback on earlier drafts of this paper. The paper also benefitted from audience comments at COSELL (Colloquium on Scholarship in Employment \& Labor Law), and at faculty workshops held by the University of Pennsylvania Wharton School of Business (Dept. of Legal Studies and Business Ethics), Wayne State University Law School, and California Western School of Law. 
applying a wholly distinct area of law. In making this argument, I draw upon two pending antitrust cases involving Uber, Uber drivers, and Uber consumers.

INTRODUCTION 234

I. A PUZZLE ABOUT PRICE-FIXING .......................................................... 238

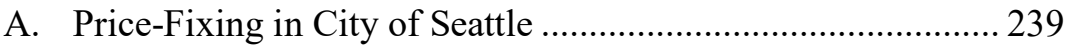

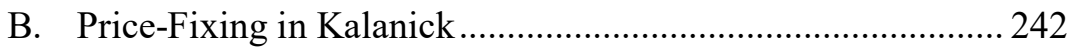

II. UBER AS FoR-PROFIT HIRING HALL.................................................. 248

A. Uber Operates in Salient Respects as a Hiring Hall................ 249

B. The Difference Between Uber and a Hiring Hall and Its

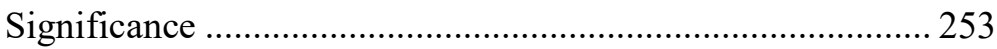

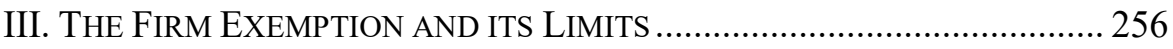

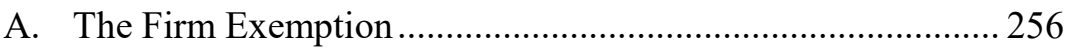

B. The Firm Exemption and Current Regulatory Treatment of



C. The Firm Exemption and Contractor-Based Firms Generally 258

\section{INTRODUCTION}

Status quo regulation of Uber has enabled it to administer what is in effect a for-profit, virtual hiring hall in the ride services market. In other words, it has been permitted to benefit from the collective economic power of Uber drivers as a group, while Uber drivers themselves have been barred from doing so-an inconsistent application of antitrust norms. The Uber example heightens a more general regulatory tension that characterizes all markets in which services are performed by putative independent contractors and prices for those services are set by firms. In two recent high-profile cases, Meyer v. Kalanick ${ }^{1}$ and Chamber of Commerce v. City of Seattle, ${ }^{2}$ Uber has pressed against drivers' coordination on antitrust grounds, while seeking to protect its own price-coordination activity from antitrust scrutiny. These litigation positions serve to dramatize a tension that inheres in status quo regulation of Uber and of independent contractor service providers more generally.

1. Complaint, Meyer v. Kalanick, 174 F. Supp. 3d 817 (S.D.N.Y. 2016) (No. 1:15-CV-9796), 2015 WL 9166194.

2. Complaint, Chamber of Commerce of the U.S. v. City of Seattle, 2016 WL 836320 (W.D. Wash. Mar. 3, 2016) (No. 2:16-CV-00322). 
Antitrust law generally forbids sellers of a commodity from coordinating among each other regarding the price of that commodity. That prohibition on price-fixing extends to express agreements to set a price, to joint bargaining with buyers, and to lesser coordination that would affect price, such as an agreement to restrict supply. Sellers of labor are exempted from this prohibition, and may coordinate the price of their labor. This exemptionthe labor exemption-creates the space for affirmative protections of collective bargaining by workers with their employers over wages and working conditions. Historically, the rationale for the labor exemption was that there are many reasons to treat labor differently from other commodities - or that perhaps it is not a commodity at all. ${ }^{3}$ The debate about those reasons and what they require of regulation is ongoing today, particularly as questions of labor law failure and potential reform increasingly predominate. ${ }^{4}$ This paper sets aside these important questions, and focuses on a slightly different matter, that nevertheless has implications for a broad swath of contemporary workers and perhaps ultimately also for labor law reform. To wit, while it is near-axiomatic that firms have the right to set prices, Uber tests the limits of intra-firm immunity from price-fixing liability, and it does so by reorganizing its relationship to those who perform work. It turns out that the "firm exemption" from antitrust, as I will call it, has significant implications for workers and work regulation.

This paper explores the largely unstated firm exemption, and its limits, by considering the Uber example. It is useful to have some salient aspects of the labor exemption in relation to today's economy and workplace in mind before we do this. Conventionally, the labor exemption from antitrust marks the boundary between labor law's protection of collective action and collective bargaining on the one hand, and antitrust law's punishment of it on the other. The key statutory sources of the labor exemption are the Norris-La Guardia Act and the Clayton Act, whose relevant provisions are knit together in two foundational New Deal-era cases, Apex Hosiery and Hutcheson. ${ }^{5}$ The labor exemption has been understood to be delineated by the boundaries of

3. The Clayton Act, Congress' first attempt at creating a labor exemption, famously declared that "the labor of a human being is not a commodity." Clayton Act, ch. 323, § 1, 38 Stat. 730 (1914) (codified as amended at 15 U.S.C. $\S \S 12-27,29$ USC $\S 52-53$ (2012)). The Clayton Act was rendered a dead letter by a hostile judiciary shortly after it was widely hailed as "labor's Magna Carta," and its revival during the New Deal via the Norris La Guardia Act and subsequent case-law was considerably more muted in its underlying rationale. See generally Sanjukta M. Paul, The Enduring Ambiguities of Antitrust Liability for Worker Collective Action, 47 LOY. U. CHI. L.J. 969, 1020-33 (2016); Norris-La Guardia Act, ch. 90, 47 Stat. 70 (1932) (codified as amended at 29 U.S.C. $\S \S 101-15$ (2012)).

4. See, e.g., Kate Andrias, The New Labor Law, 126 Yale L.J. 2 (2016) (arguing that local regulation, including for example the City of Seattle ordinance discussed herein, is a significant component of the "new labor law" that is emerging as federal labor law is failing).

5. Apex Hosiery Co. v. Leader, 310 U.S. 469 (1940); United States v. Hutcheson, 312 U.S. 219 (1941). For a slightly more detailed discussion of the law of the labor exemption and its limitations, see Paul, supra note 3, at 1020-33. 
the employment relationship, ${ }^{6}$ a coextension that resulted from foundational case-law rather than express statutory language (in contrast to other key statutes that regulate work relationships, such as the Fair Labor Standards Act, etc.). In fact, the distinction between employees and non-employees was simply not a very legally salient one prior to the New Deal, partly because of the relative paucity of legislative work regulation. ${ }^{7}$ Although there are limited exceptions to that coextension, those recognized exceptions are nevertheless still derivative of the employment relationship in concept and purpose, and their applicability to the growing number of workers who labor outside the bounds of employment is very limited. ${ }^{8}$ Yet as I have previously argued, the particular delineation of the labor exemption we have - as bounded entirely by the employment relationship - is something of a historical accident, and is not inevitable on the deeper logic of the doctrine. ${ }^{9}$

In this paper, though, I put aside the issue of what the bounds of the labor exemption ought to be, and more generally, whether there are independent reasons to permit workers who are legally independent contractors to engage in collective action as sellers. Instead, I make the argument that so long as a firm is permitted to set prices, in the consumer market, for services performed by any set of individuals (whether they are denominated independent contractors, employees, or something else), a consistent application of pricefixing norms requires that such individuals be permitted to engage in collective action with respect to their bargains with such a firm. This argument is based upon a principle of basic consistency in applying norms already contained in the existing regulatory system, and not upon introducing

6. See, e.g., L.A. Meat \& Provisions Drivers Union, Local 626 v. United States, 371 U.S. 94, 100 (1962) (antitrust law barred independent contractor drivers from union membership); Taylor v. Local No. 7, 353 F.2d 593 (4th Cir. 1965); Spence v. Se. Alaska Pilots' Ass'n, 789 F. Supp. 1007, 1011 (D. Alaska 1990) (union of independent contractor pilots impermissible under antitrust).

7. Indeed, arguably it was that broader social category - a movement of working people, whether or not they were employees - that was causally operative in the passage of New Deal worker-protective legislation, even though some in that category were later excluded from its benefits. See, e.g., Columbia River Packers Ass'n v. Hinton, 315 U.S. 143 (1942) (collective action by a group of fishermen organized as a local of the Congress of Industrial Organizations held not to qualify for the labor exemption to antitrust law).

8. One of the two traditional exceptions is the Carroll exception, which allows a labor organization that already represents a critical mass of employees in a given workplace or sector to also represent independent contractors doing the same work; the basis for the exception is those employees' statutorily recognized interest in effective bargaining, not any right or interest belonging to the independent contractors. Am. Fed'n of Musicians v. Carroll, 391 U.S. 99 (1968). The second traditional exception is the Milk Wagon Drivers exception, which permits independent contractor workers who are organizing specifically toward employee status to engage in collective action under the labor exemption. Milk Wagon Drivers' Union Local No. 753 v. Lake Valley Farm Prods. Inc., 311 U.S. 91 (1940). Neither exception would cover Uber drivers engaging in collective bargaining under a scheme such as the Seattle ordinance, nor engaging in unilateral concerted action in an effort to affect their rates of pay. They also would not protect independent contractor workers in other industries engaging in the same activities. See also Paul, supra note 3, at 1032-33.

9. Paul, supra note 3 , at 1020-32. 
additional principles or reasons. It takes no position on whether Uber drivers, or other service providers, are employees or independent contractors; rather, it implies that even if they are not employees, they are entitled to collective action rights, so long as Uber or any other firm is permitted to set prices in the services they perform.

In Part I, I argue that Uber simultaneously benefits from the enforcement of price-fixing norms in the bargain between itself and Uber drivers, and from the non-enforcement of price-fixing norms in the bargain between itself and Uber riders. To demonstrate the paradoxical character of the status quo regulatory structure in which Uber does business, I draw upon the Kalanick case, in which a consumer challenges Uber's business model as price-fixing, and the City of Seattle case, which -on price-fixing grounds-challenges Uber drivers' rights to engage in collective action with respect to their bargains with Uber. In Part II, I suggest that Uber's activity can be understood as a twist on a familiar creature of organized labor: the hiring hall. The Uber app matches riders with drivers based on location, uses a pricing algorithm to set the fare for a ride, and provides a mechanism for riders to pay drivers. It collects a percentage of the fare, characterizing that portion as a "software licensing fee." 10 This physical and economic coordination between sellers and buyers of a service, together with the economic benefit of price coordination it entails, is precisely what makes a hiring hall what it is. The key difference is that a hiring hall is set up to distribute that premium to workers themselves, while Uber is not. And there is a problem: the labor exemption, which is the ultimate authorization of a hiring hall's economic coordination, neither applies to Uber's coordination as a doctrinal matter nor ought it protect Uber's coordination as a normative matter. That leaves what we might call the firm exemption. In Part III, I explain how the Uber model pushes the limits of a firm's prerogative to set prices. As firms reinvent themselves, particularly in relation to those who perform services, they resurface the long-buried question of intra-firm immunity from price-fixing liability, and what its justifications and purposes are. I suggest that neither Uber, nor more traditional service-sector firms that sell services performed by individuals who are barred from engaging in economic coordination themselves ought to be permitted to set prices. If that renders the firms untenable, the solution is to extend the right to engage in such coordination to the individuals who perform the services.

This could be achieved in more than one way. A collective bargaining mechanism, such as the one Seattle has created for drivers in its local ride services market, would resolve the tension most directly, by allowing workers to coordinate the prices of services they perform and that the firm

10. Meyer v. Kalanick, 174 F. Supp. 3d 817 (S.D.N.Y. 2016). While the order technically adopts the facts alleged by the plaintiff, Meyer, the facts I have introduced here are relatively incontrovertible. 
sells. Worker co-operatives or other worker ownership of service-sector firms would resolve the tension by combining two separate markets into one: those who perform the services also become the sellers who set prices in the consumer market. These possibilities, and others, will have various comparative merits and demerits as a policy matter. The aim of this paper is not to advocate a particular policy solution, but to articulate an underlying principle that would ground any of them.

I.

\section{A PUZZLE ABOUt PRICE-FIXING}

The regulatory structure in which Uber and other similar ride-services firms ${ }^{11}$ currently operate enacts an inconsistency: it permits Uber to engage in price coordination of ride services and bars Uber drivers from engaging in price coordination of the very same commodity. This regulatory structure, however, is somewhat unstable and dynamic, as the litigation discussed here shows. Seattle's ordinance would effectively undo the inconsistency by extending the right to engage in price coordination to Uber drivers, and the antitrust lawsuit against Uber would undo the inconsistency in the opposite direction - by eliminating Uber's ability to engage in price coordination. Meanwhile, the Chamber of Commerce's challenge to the Seattle ordinance on antitrust grounds, together with Uber's defense of its own price coordination in the lawsuit against it, together give voice to the status quo and its contradictions.

Uber wants to deny its drivers the right to collectively bargain over their payment, while also setting prices that raise costs for riders and enhance profits for Uber. Taking Uber's ${ }^{12}$ position in Kalanick together with the U.S. Chamber of Commerce's ${ }^{13}$ position in City of Seattle, we derive the following proposition: price-fixing norms ought to regulate the market in which Uber

11. I mean to include here all firms with the same basic structure as Uber, which will be discussed in more detail in Part II.

12. Uber was not originally named as a defendant, but its chief executive officer was. As a principal, his statements and contentions are directly attributable to Uber. Beyond this, Uber's acts and the structure of Uber's business model — rather than extraneous conduct by Kalanick - are the central issues in the case. Finally, Uber was added to the case as a required party under Fed. R. Civ. P. 19(a). Meyer v. Kalanick, No. 15 CIV. 9796, 2016 WL 3509496 (S.D.N.Y. June 20, 2016). Hence, for clarity, I will often simply refer to defendants' contentions in the case as Uber's.

13. The Chamber of Commerce purports to represent the interests of Uber and similarly situated firms in bringing the lawsuit; it asserted standing on the basis of this representative capacity: "The Chamber has presented evidence that Uber Technologies, Inc., and Eastside for Hire, Inc., are members of the Chamber of Commerce and qualify as 'driver coordinators' under the Ordinance. The Chamber asserts that these members face a substantial risk of future injury and are suffering present harm as a result of the Ordinance." Chamber of Commerce v. City of Seattle, C16-0322RSL, 2016 WL 4595981, at *2 (W.D. Wash., August 9, 2016). The linchpin of its complaint also involved a defense of Uber's business model and current operations - specifically, against the alleged threat posed by drivers' collective bargaining. Id. 
and Uber drivers bargain with each other, and price-fixing norms ought not regulate the bargain between Uber and Uber riders. This is paradoxical, for it implies that Uber is entitled to derive an economic benefit from a premium from coordination in the price of ride services, at the expense of Uber riders, while Uber drivers are not entitled to benefit from the premium, for precisely the antitrust reasons that-if one accepts them-ought to prevent Uber for doing so.

\section{A. Price-Fixing in City of Seattle}

In the final month of 2015, the City of Seattle passed an ordinance that grants collective bargaining rights to drivers for taxicab, limo, and "transportation network companies" (encompassing Uber, Lyft and other companies in the ride services sector) who are classified as independent contractors rather than employees (hereinafter "the Seattle ordinance"). ${ }^{14}$ The ordinance creates a process for the certification of an exclusive worker representative, which will negotiate on behalf of drivers who contract with a particular "driver coordinator" or transportation network company as to "terms and conditions of work," including entering into a contract on behalf of those drivers that sets out such terms and conditions. ${ }^{15}$ In this the ordinance parallels the basic function and structure of the National Labor Relations Act: it provides a mechanism for workers to collectively, rather than individually, bargain for the terms and conditions of their work, on the premise that they are not able to do so effectively on an individual basis. ${ }^{16}$ Yet the ordinance is novel in that it guarantees collective bargaining rights to workers without requiring the threshold showing of employee status, as the NLRA and its state analogues generally do. Seattle subsequently released some of the key regulations implementing the ordinance. ${ }^{17}$

14. Seattle Council Bill 118499 (codified at SEATtLe, WASh., Mun. CodE $\S \S 6.310 .110-735$ (2015)) ("An ordinance relating to taxicab, transportation network company, and for-hire vehicle drivers . . . authorizing the election of driver representatives.").

15. See Seattle, Wash., Mun. Code $§ 6.310 .110$ ("Definitions"); id. at $\S 6.310 .735$ ("Exclusive Driver Representatives"), providing, inter alia, that the City will determine which organizations may qualify as potential driver representatives under the ordinance; that covered firms will provide contact information for drivers to potential driver representatives within a certain time-frame; that representation for collective bargaining purposes will be determined by submitting "statements of interest" from a majority of drivers to the City; and that subjects of mandatory bargaining once a representative is certified include, inter alia, the economic content of the contract between drivers and the firm as well as hours and working conditions.

16. Id. The ordinance notes that there "is currently no effective mechanism for for-hire drivers to meaningfully address the terms and conditions of their contractual relationship with the entity that hires, contracts with, or partners with them. For-hire drivers lack the power to negotiate these issues effectively on an individual basis." 16. Seattle Council Bill 118499, at 2.

17. Seattle.gov, Business Regulations: For-Hire Driver Collective Bargaining, https://www.seattle.gov/business-regulations/taxis-for-hires-and-tncs/for-hire-driver-collectivebargaining (last visited April 1, 2017). The Director's Rules include FHDR-1 ("Qualifying Driver and 
The Chamber of Commerce sued the City of Seattle, challenging the ordinance as preempted by federal antitrust law. ${ }^{18}$ The lawsuit characterized the purpose of the Sherman Act as protecting and promoting "market freedom," and described the "on-demand economy" typified by Uber and similar firms as the natural consequence of this market freedom and of the "exceptional" American "entrepreneurial tradition." ${ }^{19}$ The lawsuit challenged the Seattle ordinance on the ground that the regulation threatens the operation of market freedom and the entrepreneurial model of the on-demand economy. Suggesting that they are the same thing, it alleged that the Seattle ordinance constitutes an illegal restraint of trade under the Sherman Act, ${ }^{20}$ because the collective bargaining contemplated by the ordinance constitutes illegal pricefixing in ride services.

Although the actual contest in City of Seattle is likely to take place to a large extent upon the terrain of the state action exception to antitrust, lurking beneath that issue is the deeper question of the proper interpretation of pricefixing law itself. ${ }^{21}$ The dominant interpretation of price-fixing law, which is

Lists of Qualifying Drivers”), FHDR-2 (“Application Process for Designating a Qualified Driver Representative"), FHDR-3 ("Certification of an Exclusive Driver Representative"), and

FHDR-4 ("Subjects of Bargaining between a Driver Coordinator and an Exclusive Driver Representative").

18. Complaint, City of Seattle, 2016 WL 836320, supra note 2. The suit discussed in this paper was later dismissed without prejudice under Article III's Case or Controversy requirement because, the ordinance not yet having been implemented, the Chamber could show no non-speculative injury flowing from the complaint's allegations, to it or its members. Chamber of Commerce v. City of Seattle, C160322RSL, 2016 WL 4595981 (W.D. Wash., August 9, 2016). That ruling did not reach the merits of the core issue of antitrust preemption. The court's analysis relied on the fact that the ordinance had not yet been implemented and that it would be premature to presume that a union or other organization would necessarily attempt to organize Uber or Eastside drivers under the ordinance-rendering a later revival of the lawsuit very likely. Indeed, as this article was going to press, the Chamber did revive its challenge to the Seattle ordinance by filing a substantially similar lawsuit. Complaint, Chamber of Commerce v. City of Seattle, No. C17-0370RSL (March 9, 2017), 2017 WL 1073503. The new lawsuit adds allegations regarding Lyft (as a member of the Chamber), as well as other new allegations meant to bolster the Chamber's standing. In its core legal contentions - those that are material to the argument of this paperit is substantially the same legal challenge to Seattle's collective bargaining ordinance. Thus, the paper continues to make reference to the original complaint.

19. Complaint, City of Seattle, 2016 WL 836320, supra note 2, at 9ף 2, 5.

20. Id. at 9 6-8.

21. Generally speaking, a state, or a municipality authorized by a state, is permitted to step in and regulate a market in a manner that might otherwise be considered illegal suppression of competition if coordinated directly by sellers. Parker v. Brown, 317 U.S. 341 (1943). In that seminal case establishing what has come to be known as Parker immunity, a state was allowed to effectively restrict supply or output - a classic price-fixing violation under the dominant interpretation of price-fixing law if accomplished by private agreement among sellers. The state program in Parker also permitted direct regulation of commodity prices. Two key issues in determining the applicability of the Parker doctrine in the City of Seattle case are likely to be the extent to which the City's ordinance is authorized and supported by state (Washington) policy, and the extent and nature of the City's supervision over the policy it has created. In apparent anticipation of the first issue, the revised ordinance states, "the state of Washington, in Revised Code of Washington 46.72.001 and 81.72.200, has authorized political subdivisions of the state to regulate for-hire drivers and for-hire transportation services without facing liability under federal 
enthusiastically adopted by the Chamber's lawsuit, punishes all cooperation between sellers without regard to their material circumstances and without regard to the existing concentrations of power in the market at issue. The linchpin of the Chamber's complaint aggressively extends this interpretation to the rapidly growing sector of gig economy workers, to whom it has never before been applied. While that interpretation is partially the result of the limits of the labor exemption, it is also the result of developments that are entirely internal to the law of price-fixing, rather than about fixing its borders. Over much of the last century, the law of price-fixing grew away from considering market power and related considerations, and toward an intensification of the per se rule about price coordination (and economically equivalent coordination by sellers, such as coordination of supply). ${ }^{22}$ The apotheosis of this tendency is well-represented by Trial Lawyers and Professional Engineers. Both cases involved groups of individual or microenterprise service-providers whose coordination or collective action the Court deemed to be price-fixing while refusing to consider whether the coordination or resultant prices were reasonable. In Professional Engineers, even coordination over non-price elements of consumer bargains (safety and quality standards) within a professional trade group was deemed anticompetitive. ${ }^{23}$ Trial Lawyers censured collective action by a group of panel attorneys who represented indigent defendants and were paid low hourly rates, rates that essentially all the relevant agreed did not serve public policy. ${ }^{24}$ These are precisely the cases cited in the City of Seattle complaint for its core theory: ${ }^{25}$

antitrust laws." Seattle Council Bill 118499, supra note 14. The Chamber's new complaint, meanwhile, claims that:

"No provision of Washington law clearly articulates or affirmatively authorizes collective bargaining for independent contractors generally, or specifically authorizes for-hire drivers to collectively bargain with driver coordinators over the prices and terms for which drivers' services will be offered. Furthermore, the Ordinance does not (and cannot) ensure that the State of Washington will actively supervise the collective bargaining process and results to the extent required." Complaint, City of Seattle, 2017 WL 1073503, supra note 18, at 95.

The district court recently granted the Chamber's request for a preliminary injunction, temporarily staying the enforcement of the ordinance, largely on the ground that there is sufficient uncertainty regarding the application of Parker immunity given the largely undeveloped factual record. Chamber of Commerce v. City of Seattle, No. C17-0370RSL, 2017 WL 1233181, at*3, *10 (W.D. Wash. Apr. 4, 2017). The court's order-which looks dimly on the Chamber's likelihood of success on any of its other causes of action (besides antitrust) - implicitly acknowledges the underlying, novel question of the proper intersection of antitrust and labor regulation, in the significant new factual context of gig economy work, raised by the contest: "The issues raised in this litigation are novel, they are complex, and they reside at the intersection of national policies that have been decades in the making. The public will be well-served by maintaining the status quo while the issues are given careful judicial consideration as to whether the City's wellmeaning Ordinance can survive the scrutiny our laws require." Id. at*9.

22. See Paul, supra note 3, at 1036-1040.

23. Nat'l Soc'y of Prof'l Eng'rs v. United States, 435 U.S. 679, 693-94 (1978).

24. Fed. Trade Comm'n v. Superior Court Trial Lawyers Ass'n, 493 U.S. 411, 424 (1990).

25. Id. at 950 . 
Under $\S 1$ of the Sherman Antitrust Act, a "contract, combination in the form of trust or otherwise, or conspiracy, in restraint of trade or commerce among the several States" is illegal. 15 U.S.C. $§ 1$. As the Supreme Court has repeatedly held, this provision forbids independent economic actors-such as independent contractors - from colluding on the prices they would accept for their services or otherwise engaging in concerted anticompetitive action in the marketplace. [citing FTC v. Sup. Ct. Trial Lawyers Ass'n, FTC v. Ind. Fed'n of Dentists, and Nat'l Soc. of Prof. Eng'rs v. United States] Specifically, collective bargaining by independent contractors over the price and terms of a service is per se illegal under $\S 1$ of the Sherman Act. [citing Nat'l Soc. of Prof. Eng'rs].

This tendency is mostly latent in the sense that the labor exemption has protected most individual workers from this aspect of price-fixing law for most of the twentieth century and has blunted or obscured some of its more extreme implications. ${ }^{26}$ Of course, the reach of the labor exemption is waning precisely to the extent that the performance of services in the contemporary economy shifts from firms operating on an employment model to (various) organizational forms that do not involve the employment relationship. This receding of the labor exemption thus exposes the starker implications of the law of price-fixing for sellers who lack wealth and market power.

The theory of the complaint, and the rule of price-fixing law upon which it relies, implies that any price premium realized by coordination in the price of services, such as ride services, is a violation of the Sherman Act. The Chamber of Commerce in City of Seattle seeks to maintain the regulatory space that Uber has relied upon thus far, to wit, one in which Uber drivers do not have the right to engage in collective action or collective bargaining regarding the terms and conditions of their work. In its attack on the ordinance, the Chamber's litigation position draws out commitments embedded in that status quo: that price-fixing should prohibit price coordination among sellers of a service (regardless of their size, wealth or market power).

\section{B. Price-Fixing in Kalanick}

In Kalanick, as in City of Seattle, Uber is also defending an aspect of the status quo, but here that entails shielding rather than prohibiting coordination

26. However, it is important to note that Uber and the gig economy do not represent the first such deployment of price-fixing law against the collective action of non-employee workers, although it is garnering far more attention than prior deployments. For example, the same rule undermined the efforts of port truck drivers, primarily low-wage immigrant workers, to improve their circumstances starting in the early 1980 's, and profoundly shaped the direction of the national campaign that was eventually formed to address their situation. Paul, supra note 3, at 979-84. The rule also affected the organizing of home health care workers, and scattered grassroots efforts by other low-wage workers, primarily drivers in nondrayage trucking sectors, to improve their wages and working conditions. Id. at $983 \mathrm{nn} .49-51$. 
in the price of ride services. The status quo regulatory structure in which Uber operates currently permits Uber's price coordination activity.

Kalanick is a putative class action lawsuit brought on behalf of Uber riders, alleging an illegal price-fixing conspiracy in violation of Section of 1 of the Sherman Act. ${ }^{27}$ In this, its basic legal theory is identical to that of City of Seattle. The core issue it presents is this: "plaintiff alleges that Uber drivers agree to participate in a conspiracy among themselves when they assent to the terms of Uber's written agreement . . . and accept riders using the Uber app." ${ }^{28}$ The plaintiff thus posits Uber itself, in place of City of Seattle's "exclusive worker representative," as the mechanism of the illegal price coordination. ${ }^{29}$ At its essence, Kalanick surfaces a long-buried issue that parallels the more visible matter of the labor exemption: the limits of the firm exemption from price-fixing law, whereby intra-firm price coordination is immunized. ${ }^{30}$ Ironically, it is Uber's innovative self-conception ${ }^{31}$ — which has lent legal traction to its bypassing of traditional labor regulation-that is ultimately responsible for this resurfacing.

Kalanick's basic theory of liability also implies that collective action by Uber drivers ought not to be permitted. Thus, on its own it should be seen as cold comfort by critics of Uber who are also worker advocates. Some such advocates have criticized the Uber "disruption" for wreaking havoc on existing workers', mainly taxi drivers', livelihoods as well as being bad for Uber drivers. ${ }^{32}$ A loss for Uber in Kalanick would only worsen both of these effects by driving down rates of pay even further. ${ }^{33}$

The Uber app matches riders with drivers based on location, uses a pricing algorithm to set the fare for a ride, and provides a mechanism for riders to pay drivers. It collects a percentage of the fare, characterizing that portion as a "software licensing fee." 34 The price set by Uber is mandatory:

27. Complaint, Meyer, 174 F. Supp. 3d 817, supra note 1.

28. Meyer v. Kalanick, 174 F. Supp. 3d 817, 822 (S.D.N.Y).

29. See supra note 13

30. See also Paul, supra note 3, at 1016-19 (describing the background and history of the "corporate exemption" to price-fixing law). The current manifestation of this issue as raised in Kalanick is further unpacked and explained in Part III, infra.

31. Uber's insistence that it is not a transportation company and instead simply the purveyor of software platform, is discussed further in Part II.

32. Advocates for low-wage workers have deep concerns about low pay and poor working conditions not only of Uber drivers, but also of taxi drivers, whose livelihoods are directly affected by Uber. The National Employment Law Project's report on the "on-demand economy," including Uber, is a useful summary and articulation of these concerns and some of the data that supports them. Rebecca Smith \& Sarah Leberstein, Rights on Demand: Ensuring Workplace Standards and Worker Security in the On-Demand Economy, NATIONAL EMPLOYMENT LAW Project (2015), http://www.nelp.org/content/uploads/Rights-On-Demand-Report.pdf.

33. As significantly, it would add to the logical and ideological ballast behind the prohibition on collective action on the part of Uber drivers and similarly situated workers.

34. Meyer v. Kalanick, 174 F. Supp. 3d 817, 820 (S.D.N.Y). While the order technically adopts the facts alleged by the plaintiff, Meyer, the facts I have introduced here are relatively uncontroversial. 
drivers do not have the ability to set their own price or to depart from the price set by the app. ${ }^{35}$

The lawsuit is motivated in large part by Uber's "surge pricing" practice, wherein fares may rise up to tenfold the standard in times of high demand, and much of the attention on the case (as well as a good portion of the complaint and motion practice) has been focused on this. ${ }^{36}$ In its ruling on Kalanick's motion to dismiss, the court analyzed the plaintiff's allegations in terms of two possible species of price-fixing liability: a horizontal or a vertical price-fixing agreement or conspiracy. A horizontal conspiracy is an agreement between direct competitors on price; it is the paradigm case of price-fixing. As such, it is subject to the per se rule, which means that the agreement is prohibited on its face, regardless of its consequences or context. ${ }^{37}$ Not even the reasonableness of the resultant prices, nor other procompetitive effects of the agreements, are a defense. ${ }^{38}$ Generally speaking, vertical restraints involve agreements or conditions, regarding or affecting price, imposed by an actor upon downstream sellers. The regulation of vertical restraints affecting price is more complex and subject to more exceptions than that of horizontal restraints; courts consider such restraints' overall effects under the rule of reason..$^{39}$ Unlike the per se rule, the rule of reason allows a decision-maker to consider the effects of an agreement or

35. In the lawsuit, Uber has officially denied that the prices set by the app are mandatory and asserted that drivers can depart downward. $I d$. at 821 . But this official denial must be understood in context: at this stage in litigation it is entirely customary for defendants to deny even some of the most incontrovertible allegations, if they are material to the bases of liability in plaintiff's complaint. In fact, defendant's own briefing concedes that Uber sets prices, characterizing its "pricing algorithm" as necessary to its market entry as a new brand, and characterizing use of the pricing algorithm by drivers as a "condition" of Uber's agreements with drivers, Memorandum of Law in Support of Defendant Travis Kalanick's Motion to Dismiss at 13, 16-17, Meyer v. Kalanick, 174 F. Supp. $3 d 817$ (S.D.N.Y. 2016) (No. 1:15-CV-09796), 2016 WL 2731518. It is unlikely that Uber will deny that it sets prices, and that the prices are mandatory, at the fact-finding stages of the dispute.

36. Id. Unlike taxi fares, which are typically proportional only to distance and wait-time, Uber fares may increase several-fold in times of high demand. Uber's claim is that surge pricing is necessary to meet such high demand, i.e., to get drivers on the road. In 2014, Kalanick himself responded to rider complaints about surge pricing on his Facebook page this way: "Get some popcorn FalseWe do not own cars nor do we employ driversFalse Higher prices are required in order to get cars on the road and keep them on the road during the busiest times. This maximizes the number of trips and minimizes the number of people stranded. The drivers have other options as well. In short, without Surge Pricing, there would be no car available at all." Annie Lowry, Is Uber's Surge-Pricing an Example of High-Tech Gouging?, N.Y. TIMES (Jan. 11, 2014). It is not clear that this is actually true; what is clear is that Uber can set a higher fare (that people will pay) during times of high demand. To be clear, surge pricing may overall be a better policy outcome because without it, drivers would be in even more precarious economic condition than they already are. That aside, it evidences overt price coordination by Uber.

37. For a general discussion of the per se rule, see HYLTON, ANTITRUST LAW: ECONOMIC THEORY \& COMMON LAW EVOLUTION at 117-25 (2003).

38. See, e.g., Fed. Trade Comm'n v. Superior Court Trial Lawyers Ass'n, 493 U.S. 411, 423-24 (1990); Nat'l Soc'y of Prof'l Eng'rs v. United States, 435 U.S. 679, 693-94 (1978).

39. Leegin Creative Leather Prods., Inc. v. PSKS, Inc., 551 U.S. 877, 905 (2007); State Oil Co. v. Khan, 522 U.S. 3, 22 (1997). 
arrangement to decide whether it ought to be permitted under antitrust. ${ }^{40} \mathrm{~A}$ court's analysis of vertical restraints under the rule of reason may include consideration of the primary actor's market power (whereas market power is not considered in the evaluation of horizontal restraints or agreements) ${ }^{41}$ Thus, for example, Uber's surge pricing practice may be relevant to liability under the vertical restraint theory, because it may tend to show that Uber has the market power to unilaterally set prices. However, the surge pricing issue is secondary under the core, horizontal restraint analysis. While it would certainly affect the extent of damages, liability ought to either attach or not attach on the basis of the app's mandatory pricing mechanism. This follows from the general rule that it is the fact of coordination in prices that is the issue, not whether the resultant price is reasonable or exorbitant, nor even whether the resultant price ultimately benefits the seller.

Thus, the core issue in the case, and the one with which this paper is primarily concerned, is this: "As to the horizontal conspiracy, plaintiff alleges that Uber drivers agree to participate in a conspiracy among themselves when they assent to the terms of Uber's written agreement . . . and accept riders using the Uber app." ${ }^{42}$ This framing of the contest puts Uber in the position of arguing that the agreements and relationships to be assessed are vertical, not horizontal. It argues that the fact that "a condition of [the agreement between drivers and Uber] was that the driver-partner agree to use Uber's pricing algorithm" is not sufficient to establish a single multilateral horizontal agreement, rather than many vertical bilateral agreements. ${ }^{43}$ Uber then cites a body of cases involving resale price maintenance agreements, in which manufacturers' agreements with retailers or other downstream sellers to charge minimum prices are subject to rule of reason rather than per se treatment, and are sometimes permitted under that analysis. ${ }^{44}$

Apart from the merits of the analogy to resale price maintenance agreements, it is interesting that Uber, which presses the strong version of the per se rule against coordination by Uber drivers in City of Seattle and in its articulations of its business model elsewhere, ${ }^{45}$ invokes resale price maintenance in its own defense. Resale price maintenance as a practice -and

\footnotetext{
40. See, e.g., Leegin, 551 U.S. 877.

41. See id.

42. Meyer v. Kalanick, 174 F. Supp. 3d 817, 822 (S.D.N.Y. 2016).

43. Id. at 823; Memorandum of Law in Support of Defendant Travis Kalanick's Motion to Dismiss, supra note 35 , at 13 .

44. Meyer, 174 F. Supp. 3d at 826-27; Memorandum of Law in Support of Defendant Travis Kalanick's Motion to Dismiss, supra note 35, at 13-14. See, e.g., Leegin, 551 U.S. 877.

45. Again, the City of Seattle lawsuit plainly alleges that collective bargaining by Uber drivers would constitute per se price-fixing. This is both explicitly stated in the complaint, and it is inherent in the legal theory it is advancing. "[C]ollective bargaining by independent contractors over the price and terms of a service is per se illegal under $\S 1$ of the Sherman Act." Complaint, City of Seattle, 2016 WL 836320, supra note 2, at 50.
} 
as a practice tolerated or sanctioned by antitrust and related regulation- has its roots in the "fair trade" movement spearheaded by small business-people, notably a group of California pharmacists in the 1920's and 1930's, to influence industry practice as well as to influence antitrust regulators and lawmakers. ${ }^{46}$ Resale price maintenance is an aspect of a minor strain in antitrust law that sometimes permits arrangements that may not maximize short-term competition between existing sellers in a given market, but which are justified on other grounds. ${ }^{47}$ But not only in litigation positions espoused by its representatives and principals, but also in its general self-proclaimed ethos, Uber usually purports to embody the pure competition-maximizing strain. ${ }^{48}$

The court rejected the resale price maintenance argument, correctly noting that the analogy to resale price maintenance is incoherent because on Uber's own account of its business model, Uber is not selling a commodity to drivers that drivers are then reselling to riders - which is the core structure of resale price maintenance. ${ }^{49}$ The court holds that the plaintiff's horizontal conspiracy claim is legally cognizable, under a "hub and spoke" theory of conspiracy whereby multiple express vertical agreements effect a single instance of horizontal coordination. ${ }^{50}$ Uber is the hub in this picture: both the architect and, via the app and the pricing algorithm, the mechanism of the

46. Laura Phillips Sawyer, The U.S. Experiment with Fair Trade Laws: State Police Powers, Fed. Antitrust, and the Politics of "Fairness," 1890-1938, Harvard Business School Working Paper 16-060 (forthcoming, BUSINESS HISTORY REVIEW).

47. We could call this the republican strain in antitrust law; it will be explored further in forthcoming work. See, e.g., David Millon, The Sherman Act and the Balance of Power, 61 S. CAL. L. REV. 1219 (1988) (describing the republican roots of the Sherman Act, which had more to do with guarding against the dangers of over-concentrated economic power than with maximizing market competition as an end in itself). It should be noted that both this strain and the competition-maximizing strain are potentially consistent with the overall aim of conducing toward economically efficient outcomes, although they may espouse or embody different theories about how best to do so. The aim of maximizing competition among actors in a particular market must be (at least) logically distinguished from the more general aim of conducing toward economic efficiency. That aim may be better served by coordination in particular cases, particularly in markets characterized by monopsony or other distorting factors. See, e.g., ALAN MANNing, Monopsony in Motion: IMPERfect COMPETITION IN LABOR MARKETS (2005) (against the conventional wisdom, offering a model that conceives of labor markets as fundamentally monopsonistic rather than perfectly competitive; the latter would imply that all actors, including employers, are price-takers with respect to wages). With respect to the many inconsistencies with evidence raised by the standard model, Manning describes typical responses as hewing to "the competitive model with bits bolted onto it when necessary to explain away anomalies," while the monopsonistic model is altogether simpler. Id. at 11 . At any rate, the argument herein does not rely on the correctness of one model or the other; the point is simply that it is logically possible to espouse the overall aim of economic efficiency for antitrust law without thereby committing to either the republican strain or the competition-maximizing strain.

48. The City of Seattle complaint reads in many parts like a paean to competition as a way of life in an almost romantic sense. See Complaint, City of Seattle, 2016 WL 836320, supra note 2.

49. Meyer v. Kalanick, 174 F. Supp. 3d 817, 826 (S.D.N.Y. 2016) ("Here, unlike in Leegin, Uber is not selling anything to drivers that is then resold to riders.").

50. Id. at 827-28. 
price coordination. Like the "exclusive worker representative" at issue in City of Seattle, it effects horizontal coordination in the price of ride services.

I note now, and will further discuss below, that this theory of liability would be unintelligible if Uber did hold itself out as a transportation company and engaged Uber drivers on an employment model, for a very simple reason: Uber drivers' coordination, around which the alleged conspiracy is expressly built, would be immunized by the labor exemption to antitrust. It is Uber's skirting of the employment model that raises the specter of price-fixing in the first place. Conversely, the Kalanick lawsuit also relies upon the same contention that drives the antitrust challenge to the Seattle ordinance: that coordination by individuals selling their services - perhaps nothing more than their labor-ought to be prosecuted as a price-fixing conspiracy, regardless of reasonableness of price and regardless of market power, so long as those individuals are not employees.

Critics and boosters of Uber often tend to either undervalue or overvalue the role of the app. A skeptic may cast the app as little more than a diversionary tactic for regulatory avoidance by Uber. ${ }^{51}$ Meanwhile, Uber and many of its defenders seem to characterize the app as so powerful that it may dispense a wisdom that is independent of the humans who control it. ${ }^{52}$ In fact, Uber's model, which matches drivers to riders by use of a smartphone app, dispensing with a dispatcher or with the need to physically sight and hail a $\mathrm{cab}$, seems to be a genuine operational innovation. This technology affects the speed of the transaction, the cost, and the wait-time. As a result of all these - and probably also as a result of regulatory avoidance that gives Uber and similar firms an obvious competitive advantage over taxi services that are compelled to follow existing regulations - many more riders and drivers are brought into the market for exchanging rides for money. But there is no need to suppose that the changes that Uber has wrought in this market must all be due either to operational innovation on one hand, or to regulatory arbitrage on the other. ${ }^{53}$

A specific peril of overvaluing the app is the conflation of a new means of accomplishing an old purpose with the undertaking of an entirely new purpose, particularly where the applicability of a set of regulations turns on that distinction. This sometimes leads, in the context of Uber and other gig

51. A common criticism of Uber in the public debate is that the main driver of its success is regulatory arbitrage - avoiding the costs of local regulation that existing ride service providers, such as taxis, must bear. See, e.g., Dean Baker, "Don't buy the 'sharing economy' hype: Airbnb and Uber are facilitating rip-offs," THE GuARDIAN (May 27, 2014, 7:30 AM), https://www.theguardian.com/commentisfree/2014/may/27/airbnb-uber-taxes-regulation.

52. The way that Uber talks about its surge pricing practice is an excellent example of this. See Lowry, supra note 36 .

53. A more detailed assessment of the operational innovation of Uber's app-based model, which also takes into account Uber's avoidance of regulation, can be found in Brishen Rogers, The Social Costs of Uber, 82 U. CHI. L. Rev. Dialogue 85, 86 (2015). 
economy firms, to the attempted erasure of human agency. This point has been made generally about the gig economy and Uber, for example in the context of racial and other illegal discrimination. ${ }^{54}$ The point applies just as forcefully to any price coordination performed by Uber and executed by means of the app. The Kalanick court seems to share this view, namely that the app may be the means of the price coordination:

... [T] he capacity to orchestrate such an agreement is the 'genius' of Mr.

Kalanick and his company, which, through the magic of smartphone technology, can invite hundreds of thousands of drivers in far-flung locations to agree to Uber's terms. The advancement of technological means for the orchestration of large-scale price-fixing conspiracies need not leave antitrust law behind. ${ }^{55}$

The court thus rejects the conflation of the economic function of the pricing algorithm and the technological functioning of the software.

The regulatory status quo with respect to Uber seems to permit a "supracompetitive price premium" in such services, but to allocate that premium entirely to Uber. Absent a loss in Kalanick, Uber continues to derive such a premium from its price coordination; absent enforcement of a regulation like Seattle's, drivers cannot coordinate in bargaining a share of that premium. To put it another way, the regulatory status quo permits Uber to evade pricefixing norms in its bargaining with consumers, but does not allow drivers to evade them in its bargaining with Uber. If we agree that price-fixing norms either ought to govern the price of a given service, in this case ride services, or not, then status quo regulation contains a tension.

II.

UBER AS FOR-PROFIT HIRING HALL

Uber exposed itself to antitrust liability by taking the somewhat novel position that not only is it not an employer, but it is not selling ride services at all, and is instead a sort of market mediator. ${ }^{56}$ This Part suggests that this self-professed role in a market for services leads to a particular set of deeper

54. Noah Zatz, Beyond Misclassification: Gig Economy Discrimination Outside Employment Law, ONLABOR, (Jan. 19, 2016), https://onlabor.org/2016/01/19/beyond-misclassification-gig-economydiscrimination-outside-employment-law/ (comparing this obscuring of agency to other scenarios already considered in existing case law, situations which do not involve technological innovation but rather other apparent interruptions or diffusions of intent or agency).

55. Meyer v. Kalanick, 174 F. Supp. 3d 817, 825 (S.D.N.Y. 2016) (internal citation omitted).

56. Uber's characterization of itself as a market mediator is deeply explored by Julia Tomassetti in the context of firm theory and the history of the firm, in Does Uber Redefine the Firm? The Postindustrial Corporation and Advanced Information Technology, 34 HOFSTRA LAB. \&EMP. L.J. (forthcoming). As she points out, the newness of the antitrust problem presented in the Kalanick case-wherein the intra-firm price-setting prerogative is challenged as price-fixing - illustrates and confirms the newness of Uber's claims about its firm identity, although she argues that the reality of Uber's and Lyft's operations do not reflect their own self-descriptions and that Uber's self-description is ultimately incoherent. 
problems at the antitrust-labor intersection (beyond the factual matter that Uber has drawn a new type of antitrust lawsuit). An analogy helps to bring this into relief: a close precedent for Uber's business model is an institution, the union hiring hall, that is not a firm at all. The hiring hall is a useful model for understanding the regulatory space in which Uber does business, both for its functional similarities with Uber and for its main difference - the reversal of the distribution of the price premium from coordination. The analogy also gives life to the paradox that was articulated in Part I: it exposes the arbitrariness of permitting Uber to coordinate the prices of services performed by independent contractors, while prohibiting labor organizations or workers themselves from doing so.

\section{A. Uber Operates in Salient Respects as a Hiring Hall}

Uber has been most vocal about the nature of its business model in the labor cases in which it has been involved. There, it has insisted not only that it is not an employer of Uber drivers but also that it is not a transportation company and does not sell driving or ride services. ${ }^{57}$ To put this claim in context, there are three major ways that Uber's identity and market role can be conceptualized.

The first is the position taken by workers and their representatives in the Uber labor cases. Drivers have brought claims in several jurisdictions and in administrative tribunals, contending that they are legally employees of Uber denied the protections of labor and employment law..$^{58}$ Drivers' description

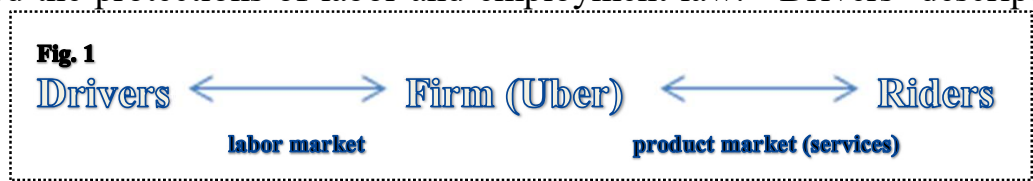

of their relationship with Uber corresponds to the conventional legal form for engaging labor under the New Deal framework of work regulation, i.e., the employment relationship, as depicted in Figure 1.

57. See, e.g., O’Connor v. Uber Techs., Inc., 82 F. Supp. 3d 1133, 1137 (N.D. Cal. 2015) (wherein Uber presents itself as a "technology company" that does not provide transportation services to passengers.).

58. For a relatively comprehensive review of these cases, and misclassification cases in the rideshare sector generally, see Pamela Izvanariu, Matters Settled but Not Resolved: Worker Misclassification in the Rideshare Sector, 66 DEPAUL L. REV. n. n.3 (forthcoming 2017) (collecting pending cases). Note that much of this litigation is quickly developing, and that new cases are being filed. Of particular note are the cases against Uber and Lyft pending in the Northern District of California, which have generated substantial national attention as well as a decisive denial of the motions for summary judgment by the firms. See, e.g., O' Connor, 82 F. Supp. 3d 1133. Thereafter, the proposed settlement in O' Connor was rejected by the court, which was not convinced that the proposed settlement sufficiently compensated or protected the interests of class members, Uber drivers. O' Connor v. Uber Techs., Inc., 201 F. Supp. 3d 1110 (N.D. Cal. 2016). 
The second way to see Uber's identity and role is as a transportation company that engages drivers on a contract, rather than employee, basis, as depicted in Figure 2. This is how many transportation companies in today's economy function, even though these arrangements have been challenged by putative independent contractor drivers as misclassification, i.e., for functionally engaging in employment relationships, but avoiding the duties and responsibilities that flow from that role under our system of labor regulation. ${ }^{59}$ The structure is similar to the traditional firm depicted in Figure 1, except that the labor market becomes a supply market, for services bought by the firm and re-sold by the firm in the consumer market.

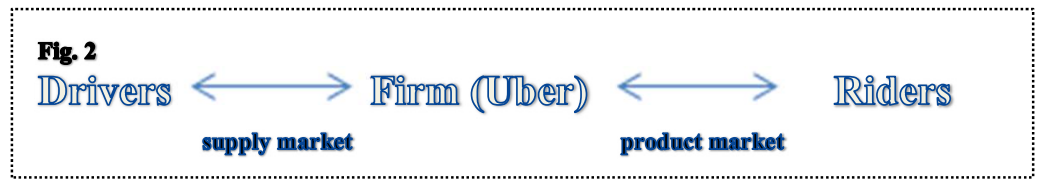

The third way to see Uber's firm identity and market role is as it has described itself, primarily in its labor cases but also in general: as a

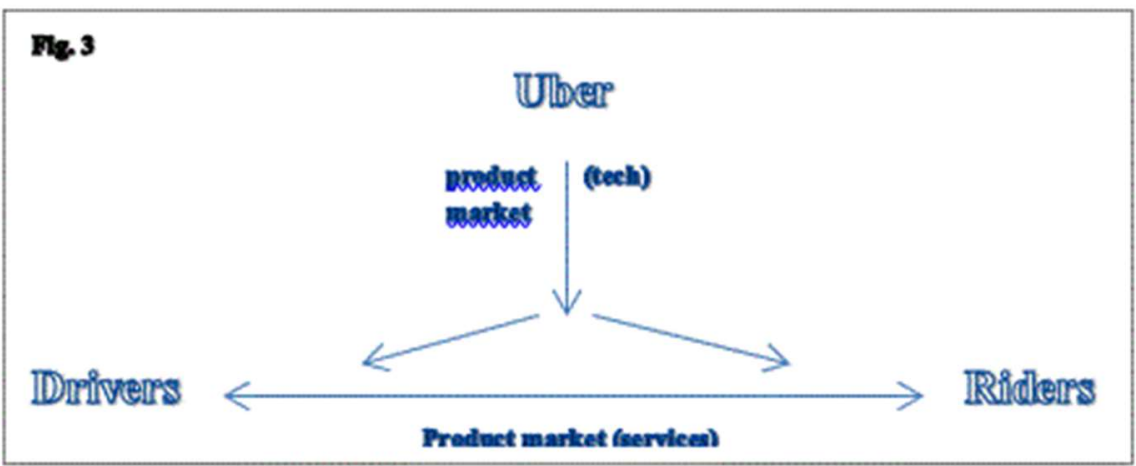

technology company selling an 'app' to both drivers and riders. On this conception, Uber's primary role is to lower transaction costs in the market between drivers and riders, perhaps to the extent of creating a market where one would not have been feasible before (due to those transaction costs).$^{60}$ Uber thereby argues it enables and innovates a firm-to-market transition in the organization of economic activity and exchange. ${ }^{61}$

59. See generally Paul, supra note 3, at Part I (describing the independent contractor arrangement and challenges thereto in trucking and other sectors). Taxi companies have also been accused of misclassification. See, e.g., Priscilla Garcia-Ocampo, Standing Up for Taxi Drivers, U.S. DEPT. OF LAB.: BLOG (Aug.19, 2015), https://blog.dol.gov/2015/08/19/standing-up-for-taxi-drivers (describing U.S. Dept. of Labor Wage \& Hour Division investigation of taxi company).

60. Rogers, supra note 53; Tomassetti, supra note 56.

61. Tomassetti, supra note 56 (describing and critiquing this conception of Uber's function). 
Uber, in the role represented in Figure 3, is said to bring about an entirely new way of doing business and of working and to disrupt the old paradigm. ${ }^{62}$ Yet the relationships depicted in Figure 3 in fact bear some structural similarities to a most hoary and traditional New Deal institution: the hiring hall. The word itself is enmeshed in associations that are anything but twentyfirst century. It may conjure images of the American docks and waterfronts of yore, and of a bygone era of work and work relations. But image and affect aside - with one crucial difference - the economic reality of the two situations is very similar.

Hiring halls historically functioned, and still function, to coordinate short-term employment in industries where jobs are by nature seasonal, fluctuating, or short-term, and where employers have a need to find workers for jobs on short notice. ${ }^{63}$ Its origins date before the New Deal era, and the NLRB was initially suspicious of the greater control that it gave workers' organizations over the work relationship itself. ${ }^{64}$ However, the Supreme Court eventually brought the hiring hall squarely within the constellation of institutions authorized under the NLRA. ${ }^{65}$ Essentially, they have three pertinent characteristics: 1) they coordinate the logistics of an interaction between workers or service providers, and engagers of labor or users of services; ${ }^{66}$ 2) they coordinate prices for those services; ${ }^{67}$ and 3 ) they exist in a regulatory structure, namely traditional labor law, that permits such price

62. See, e.g., Larry Alton How Purple, Uber and Airbnb Are Disrupting and Redefining Old Industries, ENTREPRENEUR (April 11, 2016), https://www.entrepreneur.com/article/273650. Plenty of critics, of course, argue that it does nothing of the sort, and is simply a reinstantiation of the employment relation masked by a new technology. See, e.g., Benjamin Sachs, Do we Need an 'Independent Worker' Category?, ONLABOR (blog), (Dec, 8, 2015), https://onlabor.org/2015/12/08/do-we-need-anindependent-worker-category/. As explained in the Introduction, the argument of this paper takes no position on that question, but queries what follows if Uber's self-description is accurate.

63. See, e.g., Barbara J. Fick, Political Abuse of Hiring Halls: Comparative Treatment under the NLRA and the LMRDA, 9 INDUS. REL. L.J. 339, 341-42 (1987) ("In industries characterized by work which is casual or of short-term or irregular duration, and by employers with mobile job sites, the conventional hiring methods tend to be inefficient and ineffective. In shipping, there is a need for qualified crews to work for the duration of the voyage, and for labor gangs to be available when a ship arrives in port for loading and unloading cargo. In construction, contractors require skilled workers in various craft fields. These skilled craft workers will rarely be employed for the duration of the building project; rather, different crafts are required at various stages and in varying numbers during the construction process. The hiring hall system acts to alleviate the problems encountered by both employers and employees in these types of industries.") (footnotes omitted).

64. Local 357, Int'1 Bhd. of Teamsters, Chauffeurs, Warehousemen and Helpers of Am. v. NLRB, 365 U.S. 667, 669, 672 (1961) (Board took the position that the hiring hall was illegal due to its association with the "closed shop," which is not permitted under the NLRA).

65. Id.

66. "The Board recognizes that the hiring hall came into being 'to eliminate wasteful, timeconsuming, and repetitive scouting for jobs by individual workmen and haphazard uneconomical searches by employers. .."' Id. at 672 (quoting Mountain Pacific Chapter, 119 N.L.R.B. 883, 887 n.8 (1958)).

67. A hiring hall run by a union operates under the collective bargaining scheme that is the union's primary purpose and reason for existing under the NLRA; thus, the union/hiring hall is a mechanism of concerted action as to the prices of the labor performed under its auspices. 
coordination and imposes burdens and obligations in turn ${ }^{68}$ In other words, hiring halls essentially function as market mediators in markets for services, engaging in both physical and price coordination of work relationships. In terms of their governance, they are ultimately accountable to workers themselves (who are members of the labor unions that run the hiring halls). The union that runs the hiring hall charges union dues to workers if they are members, or an agency fee to cover the hall's operating costs, if they are not. ${ }^{69}$ Because the work relationships formed in hiring halls are considered employment relationships, their price coordination is ultimately protected by the labor exemption from antitrust law. ${ }^{70}$

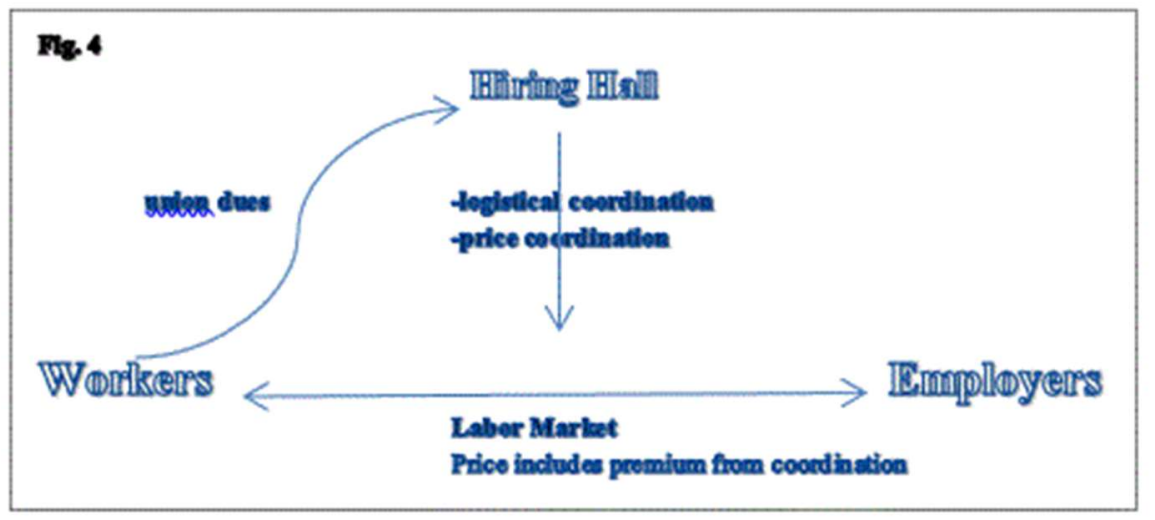

Now let's take a slightly more fine-grained look at Uber's activity. Uber purports to perform exactly the same functions as a hiring hall: it brings together buyers and sellers in time and space, and it also sets the price of the ride. Just as importantly, it insists that it does nothing else: it does not hire the driver itself, and it does not sell rides. It simply coordinates a market, physically and economically. Hiring halls perform these functions in a physical hall, while Uber embeds the hiring hall into a smartphone app. The primary function of the app is to coordinate the logistics of the interaction between Uber drivers and riders. The fact that it does so through a new medium, a smartphone app, does not alter the substance of the function.

68. As institutions subject to the NLRA and other labor law, unions that run hiring halls are subject to all its attendant obligations, which include, among other things, the duty of fair representation, the duty not to discriminate against non-members, and various reporting requirements.

69. See, e.g., Hiring Halls, NAT'L LABOR RELATIONS BD., https://www.nlrb.gov/rights-weprotect/whats-law/employees/i-am-represented-union/hiring-halls (last visited Mar. 12, 2017).

70. In other words, this justification can ultimately be traced again to the foundational labor exemption cases, which do not mention hiring halls explicitly but whose authorization of wage coordination was effectively extended to hiring hall activity when the legality of hiring halls was established. Apex Hosiery Co. v. Leader, 310 U.S. 469, 504 (1940) (workers' organizations that aim to take wages out of price competition are permitted under the labor exemption to antitrust law). 
Moreover, the fact that the coordination is effective, and therefore lowers the costs of exchange, also does not alter its basic substance. This function

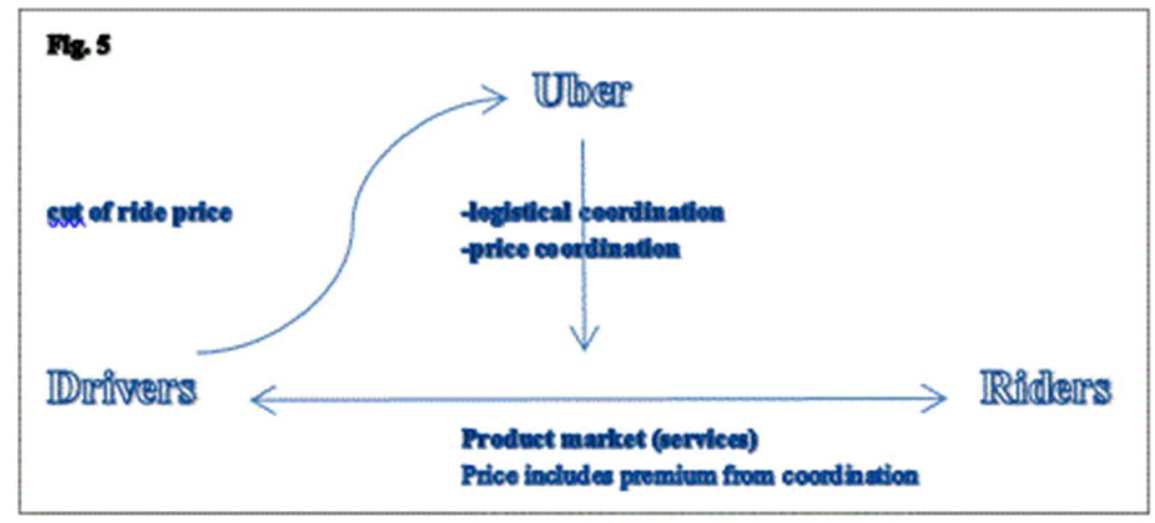

encompasses logical coordination, i.e., a means of matching and physically bringing together riders and drivers in a particular area, and it encompasses coordination in prices or direct price-setting, via the app's pricing algorithm. Finally, by its own description, Uber does little other than these core activities; it disavows the supervision, organization of work, and exclusivity of relationship that are essential to an employment relationship. ${ }^{71}$ Figure 5 is a redescription of Uber's activity that displays its structural similarities to hiring halls:

In fact, these structural similarities with hiring halls are also just what raise the specter of price-fixing liability for Uber. Uber faces price-fixing liability precisely because it has purported to diminish its role to that of market mediator, not because of a disguised expanded role. In other words, in the Uber misclassification cases, workers contend that Uber really does far more than it says it does - that it is disguising a relatively expansive role which, if properly recognized, implies liability (for employment law violations). In the antitrust threat it faces, Uber's exposure flows from what it is not doing as much as what it is doing: price-coordination, and little else.

\section{B. The Difference Between Uber and a Hiring Hall and Its Significance}

Functionally and economically, the difference between a hiring hall and Uber lies only in the distribution of the premium from price coordination that both engage in. Uber collects a fee in the form of a percentage of every fare collected. Regarding the amount of the fees charged by Uber, or Uber's "cut" of the ride price, Uber drivers are not able to exert coordinated bargaining

71. Of course, Uber makes and is committed to these contentions insofar as it claims it is not an employer, in general and in the employee misclassification cases previously discussed. See supra notes 58-59. 
power, absent a regulatory framework such as the one Uber contests in Seattle. And unlike in the hiring hall case, where the market mediator's governance structure entails that as much of the premium as possible will be passed onto workers, drivers' inability to bargain over their share of the premium entails that the distribution of the premium will favor the firm.

This primary difference between Uber and a hiring hall results from their respective reasons for existence, as far as distribution of economic benefits are concerned. Labor unions run hiring halls, and thus they represent the economic interests of the workers who participate in them. The price premium from coordination goes to workers, minus any operating costs (in the form of union dues). Uber, on the other hand, aims to maximize eventual return for its investors. It is not accountable to drivers for any price premium from coordination.

This difference between Uber and a hiring hall is significant because the distributional aspect of a hiring hall is what justifies its price coordination in a services market. The closest precedent for Uber's firm identity, the institution that arguably plays the most similar economic role, is not a firm at all, but an institution that is directly and solely accountable to workers (service providers) themselves. This lends a certain extra drama to the regulatory tension identified in Part I: the best institutional precedent for Uber's fundamental activity not only does not involve the regulatory asymmetry (to the benefit of the market mediator) previously identified, but it in fact passes all the benefit of the price coordination back to the workers/service providers. Again, that institutional precedent - the hiring hall - is enabled, as a regulatory matter, by the labor exemption from antitrust law, and thus its price coordination is ultimately justified by the fact that the benefit from coordination goes to workers. Hiring halls get to exist because the policy of the labor exemption is to allow price coordination in wages for work, for a host of reasons..$^{72}$ Those reasons include the structural inequality of bargaining power between workers and employers, social welfare norms, and distributive justice concerns. ${ }^{73}$ Those are the sorts of reasons that comprise the ultimate justification for hiring halls' price coordination activity. But those policies do not justify the asymmetric regulatory treatment of Uber and Uber drivers. In fact, those policies are hostile to this asymmetry. The combination of convergence in function and operation, and divergence in economic distribution, between Uber and a hiring hall is significant for that reason. It suggests that the existing justification for price coordination activity by hiring halls does not extend to Uber's new iteration of it. It may

72. Apex Hosiery, 310 U.S. at 503-04 (foundational labor exemption decision, that affirmed that "elimination of price competition based on differences in labor standards is the objective of any national labor organization" and does not violate the Sherman Act).

73. The point is not that there is consensus on the underlying justification for the labor exemption, but that none of the usually discussed possibilities can protect Uber's one-sided right to coordinate prices. 
not-on its own - show that there is no such justification for the Uber regulatory asymmetry, but it shows that it must be a different justification, one that Uber has not yet provided. ${ }^{74}$

An analogy can only ever be suggestive, not definitive, and what it suggests here is that the regulatory asymmetry that currently characterizes the Uber market is even more of an aberration than the articulation of it in Part I may have suggested. Hiring halls engage in market coordination very similar to Uber's, and they derive their authorization to coordinate the prices of services from the labor exemption to antitrust law. If Uber drivers were employees, then Uber would not have an antitrust problem either. Uber's coordination of the prices of services performed by Uber drivers would be indirectly immunized by the labor exemption. Of course, in that scenario, Uber drivers would also have the right to engage in collective action in furtherance of their economic interests - even collective action that would be deemed price-fixing under antitrust law in the absence of a labor exemption. They would have the right to benefit from any price premium from coordination, just as workers who are members of hiring halls do (and just as regular employee of firms do, at least de jure and in theory). Further, this connection between Uber's exposure to antitrust liability and the employment status of Uber drivers reveals a deeper doctrinal connection between antitrust law-as it applies to firms, not just to workers-and labor/employment law.

Conversely, if a hiring hall's members were independent contractor service providers, it would be engaging in impermissible price-fixing under the conventional interpretation of antitrust law. ${ }^{75}$ Yet Uber, which is functionally operating a virtual, for-profit hiring hall, has thus far been permitted to engage in precisely the same price coordination as between independent contractor service providers. ${ }^{76}$ This truly seems to be an

74. To be sure, one might compare Uber to other similar, existing institutions as well. They all confirm the same point. A job placement agency is, like Uber, a for-profit firm and it also refers workers or service-providers to a third party that engages those services. But job placement agencies do not typically set the pay rates or wages of individuals whom they refer, whether those individuals are to be employees or independent contractors; they collect a flat fee for the placement rather than a percentage. In other words, they do not set prices, engage in price coordination, or realize a premium from economic coordination between the individuals they refer. A staffing agency (or 'temp agency') typically sets wage rates as an employer, but as employees, the workers it engages have the statutory right to engage in coordination regarding those wage rates, unlike Uber drivers. A worker-owned cooperative obviates the possibility of the regulatory inconsistency altogether in that the labor/supply market and consumer market are collapsed into one, and any premium from coordination would be paid directly to worker-owners. An example of a worker-owned cooperative that sells services to consumers is $\mathrm{Si}$ Se Puede, which sells housecleaning services in Brooklyn, New York. SI SE PUEDE!, http://www.wecandoit.coop/about.html (last visited Mar. 12, 2017).

75. See Part I.A, supra, which sets out why this is the case.

76. Of course, a court may eventually determine that these service providers are employees and not independent contractors. This paper traces out implications that follow if Uber is correct in its claim that drivers are independent contractors, and in its practice of treating them as such. These implications are the 
aberrational result. Part III will explore the remaining potential explanation for this odd conjunction of features in our status quo regulatory structure.

III.

\section{THE FIRM EXEMPTION AND ITS LIMITS}

There is one remaining possibility to explain the aberrational result just described, and to distinguish the regulatory treatment of Uber from that of a hiring hall composed of independent contractors. Uber is a firm, and intrafirm price coordination is generally permitted by antitrust law. But ought Uber to be permitted to engage in the precise price coordination from which a hiring hall (or any association of workers that is not a firm) would be barred, simply because Uber is organized as a firm? This Part will explore that question, and with it the usually unstated "firm exemption" to antitrust law and its potential limits.

\section{A. The Firm Exemption}

Before evaluating whether the firm exemption ought to provide the justification for Uber's price coordination, and for status quo regulation of Uber's business model, let's briefly consider its status and history. What I am calling the "firm exemption" is the usually unstated rule that intra-firm price coordination is generally permitted under antitrust regulation. I call it the firm exemption in order to highlight the parallel with the labor exemption to antitrust law. The labor exemption, even now and in contrast to the firm exemption, is explicitly named in the doctrine and its limits articulated. In modern antitrust law, the firm exemption has the deeper status of a nearaxiom. And one can see why: in one sense it seems incoherent to even think of intra-firm price coordination as price-fixing. Firms may combine with other firms to engage in price-fixing, but price-coordination within a firm is simply what firms do.

And yet, the firm exemption was not always so firmly rooted. After the passage of the Act, there was explicit discussion and worry that business corporations themselves might be construed as contracts in restraints of trade,

same ones that will apply to substantially similar cases of gig economy firms (that may arise in the future) involving genuine independent contractors who fall outside the protections of labor and employment law. Both are significant possibilities in themselves. Moreover, if Uber drivers are employees, then as a matter of existing accepted law they are entitled to engage in collective action notwithstanding antitrust law. The argument of this paper shows that if Uber drivers are not employees, they also ought to be permitted to engage in collective action notwithstanding antitrust law-as a matter of simple consistency in our regulatory framework. In other words, it shows that Uber drivers (and similarly situated actors) ought to be permitted to engage in collective action notwithstanding antitrust law, whether they are legally employees or independent contractors. Not only is that conclusion consistent with the argument of worker advocates that Uber drivers are in point of fact legally employees, but it ultimately actually bolsters their position. The reason is that it articulates another, independent reason that individuals who perform services ought to have collective action rights. 
although those fears were soon laid to rest. ${ }^{77}$ It is important to recognize that the firm exemption may be best viewed as a function of an intersection between antitrust law and the law of corporations, just as the labor exemption lies at the intersection of antitrust law and labor law. Without a robust concept of a business corporation as a legal person, antitrust law might not have such a robust firm exemption, and might instead sometimes consider intra-firm coordination as the coordinated actions of many individuals (ultimately, owners or shareholders).

Moreover, at the time that antitrust law was forming, the employment relationship lay at the core of firm structure: one might even say that the distinctive thing about the firm was the employment relationship. ${ }^{78}$ So modern firms grew up together with employment relationship, and from the time of the New Deal on, the firm exemption would have rarely operated in a context in which the labor exemption was not also operational.

\section{B. The Firm Exemption and Current Regulatory Treatment of Uber}

Does the firm exemption provide the justification for Uber's price coordination activity that would resolve the regulatory inconsistency identified in Part I? Does it explain why Uber is currently permitted to operate as a virtual, for-profit hiring hall of independent contractors - something that a labor union (which would distribute the economic benefit of such coordination to drivers) is not permitted to do? The firm exemption as it currently exists does not justify or explain this result: neither in terms of the surface structure of the doctrine, nor in terms of the deeper purpose of the rule.

Conventionally, the firm exemption allows a firm to set prices in a commodity (service or good) that it is selling. Taking Uber's own selfdescription, as this argument does, Uber of course does not sell ride services at all. Yet, Uber also sets the price of ride services. It cannot claim the firm exemption in the straightforward sense, that it is simply doing what all other firms do. By delinking its price coordination from the commodity it is selling, Uber pushes beyond the previously tested bounds of the firm exemption to antitrust law; the simple fact that it is a firm and firms are permitted to set prices cannot automatically be presumed to immunize it. By pushing beyond the conventional bounds of the firm exemption, Uber forces us to, first of all,

77. In United States v. Joint-Traffic Association, the Supreme Court directly addressed the possibility that "business organizations ... violated the Sherman Act." Hylton, supra note 37, at 94; United States v. Joint-Traffic Ass'n, 171 U.S. 505, 567 (1898). See also Herbert Hovenkamp, Labor Conspiracies in American Law, 1880-1930, 66 TeX. L. REV. 919 (1988) (discussing contemporary commentators' defense of corporations as business combinations).

78. See, e.g., Ronald Coase, The Nature of the Firm, 4 ECONOMICA 386 (1937); Alfred Chandler, The Visible Hand: The Managerial Revolution in AMERican Business (1977). 
name this largely unstated axiom of antitrust regulation and notice its conventional boundaries.

However, Uber also forces us to ask the deeper normative question: what ought the proper bounds of the firm exemption be? Should they be left where we just noticed them- however little conscious deliberation may have determined their location, and however remote in time and circumstance that deliberation may have been? Should they be expanded to include and protect Uber, in light of its operational innovations? Should they be contracted in light of the regulatory inconsistency that the Uber case brings to light?

This paper does not address these questions exhaustively, ${ }^{79}$ although I hope to have furthered the conversation by naming them. But I will briefly review a few considerations in favor of the conclusion that the deeper version of the regulatory inconsistency in the relationship between the firm exemption and independent contract service providers in fact extends beyond Uber. So, whether the firm exemption is contracted, expanded, or left where it is, either the labor exemption must be expanded to match it, or some other mechanism must be found to permit collective action between the nonemployee service providers with whom such firms deal.

\section{The Firm Exemption and Contractor-Based Firms Generally}

Once we find ourselves querying the proper bounds of the firm exemption, we are led to question whether the regulatory inconsistency as between the collective action of workers and the collective action of owners/investors does not in fact extend beyond Uber, to other sorts of firms whose price-coordination has until now fallen within the conventionally accepted bounds of the firm exemption. In particular, service-sector firms that engage the providers of the services they sell on an independent contractor rather than an employee basis seem to fall within the current bounds of the firm exemption because they sell the services whose prices they set. Nevertheless, such firms seem to benefit from the same regulatory asymmetry as Uber.

Uber itself suggests this commonality between it and other service firms that engage independent contractor workers or service providers. In Kalanick, protesting that it is being unfairly singled out for price coordination, Uber correctly points out that car services contract with drivers (who are often independent contractors, not employees) and set prices: ${ }^{80}$

79. Ultimately, I do think that Uber's operational innovations justify the expansion of the firm exemption to allow its price-setting, but I do not think that they justify the regulatory inconsistency whereby Uber is permitted to coordinate prices in the very same commodity as to which drivers are barred from engaging in collective action. I will develop this argument further in future work.

80. Reply Memorandum of Law in Supp of Def. Travis Kalanick's Mot. to Dismiss, Meyer v. Kalanick, 174 F. Supp. 3d 817 (S.D.N.Y. 2016) (No. 1:15 Civ. 9796), 2016 WL 2731512. 
The same would be true if Uber were a car service that contracted with drivers and told them what to charge - like all car services do-and which the Supreme Court has held is neither horizontal nor forbidden by the antitrust laws.

Admittedly, Uber mixes up some issues here: it invokes the analogy between itself and car services firms, which set prices charged by drivers who are independent contractors, and in the same breath it invokes the resale price maintenance cases (discussed in Part I). But the resale price maintenance cases are not the reason that car services firms' right to set prices has not been questioned while Uber's right to do so has.$^{81}$ Rather, it is simply the fact that car services firms sell the very commodity whose prices they set-the conventional, if lightly etched, boundary of the firm exemption - while Uber purports to coordinate a market whose commodities it does not sell.

Nevertheless, Uber's litigation position hovers near a fundamental point that underlies the surface structure of the doctrine. Even if it does not lead to a lawsuit of the sort Uber is facing, the deeper tension that car services' price coordination shares with Uber's ought to trouble policy-makers. As in the case of Uber, current regulation permits the owners of a service-sector firm to set prices for the service performed by people it engages as independent contractors, rather than employees. Meanwhile, current regulation bars those people from coordinating directly among each other in their bargains with the firm, the re-seller of their services, regarding the price of the very same commodity: the service they perform. The larger the number of serviceproviders engaged by that firm - and the larger the proportion of total market share represented by that number of service-providers - the greater the economic benefit from intra-firm price coordination. For example, take the hypothetical example of a drayage (short-haul trucking) firm that serves the Ports of Los Angeles and Long Beach. This is a local market with a given demand for a certain number of loads or trips; that demand could also be expressed in terms of a certain number of driver-hours or roughly full-time drivers. Say that there is a demand for eight thousand drivers in this market, and that a particular trucking firm engages two thousand independent contractor truck drivers, while no other firm in the market engages more than a few hundred, and most engage dozens. The largest firm is likely deriving an economic benefit in virtue of its ability to a coordinate the prices of a quarter of the total services provided in the market. However, its drivers are barred from joining a union or even in engaging in ad hoc collective action

81. The resale price maintenance cases are no more apposite in the case of such car services firms than they are in the case of Uber. Car services firms do not sell a product to drivers, which drivers then resell to consumers; they buy drivers' services and resell them to riders. The same is true of other such services firms, such as trucking firms that engage drivers on a non-employee, independent contractor model. It is likely that Uber's blurring of the issues is strategic rather than the product of error, as it has the effect of buoying up both the applicability of the resale price maintenance cases to Uber, and the strength of the practical precedent provided by car services firms. 
as to their economic conditions, including rates of pay. In other words, the firm is permitted to coordinate the price of the drivers' services, and to derive an economic benefit from that coordination, but the drivers themselves are not permitted to coordinate the price of the same services - their own services. There does not seem to be a basis for permitting firms to set prices in services (and to benefit from that price coordination, either because they sell those services themselves, or because they collect the price premium from coordination in some other way, as Uber does) while prohibiting those who provide the services from engaging in price coordination directly amongst themselves, whether in their dealings with the firm or directly with customers.

Notice that this regulatory inconsistency actually goes beyond the differential treatment of combinations of capital and combinations of labor to which late nineteenth century and early twentieth century commentators sometimes referred. ${ }^{82}$ Because while there was a time when the inconsistency in treatment of owners/investors and workers/service-providers by antitrust law was actually named and discussed ${ }^{83}$ by lawyers and in the wider polity, that inconsistency seems to have been understood in terms of the differential attitude toward combining the economic power of capital and combining the economic power of labor. But owners/investors do not just benefit from combining the economic power of their capital. In markets where there is a price premium to be realized from coordination, they also benefit from combining the power of others' labor. They coordinate the prices of services others perform, through the mechanism of the firm (and thereby realize any premium), while the service-providers themselves, if they are not employees, are barred by antitrust law from benefitting from the economic power of their own combination. This is made stark in the case of service-sector firms that sell the very same services that they buy, and it is made starkest of all by Uber, which pares its activity down to this coordination - but in both cases the ultimate doctrinal basis for the differential treatment is the growing number of people who perform work but are not covered by the labor exemption to antitrust law. To put it in the older language: capital - then, and now again - benefits not only from the combination of capital but also (at least in markets where a premium may be realized from coordination) from

82. An example of this kind of commentary from that period: "[I]n these days of huge and powerful corporations, which form in the eyes of the law a single person ... why should the law be such that if two steel workers plan a certain act which the law regards as tortious, they should be subject to fine and imprisonment, but if, let us say, the United States Steel Corporation plans and executes the self-same act, the criminal law should be unable to touch it?" Francis B. Sayre, Criminal Conspiracy, 35 HARV. L. ReV. 393, 420 (1922).

83. Id. Again, the reason the matter arose at that time - prior to the New Deal—is that there was not then a labor exemption to antitrust law. The reason it arises now is that a growing number of people who perform work or services fall outside the protection of that labor exemption because they are not employees. 
the combination of labor, while labor is denied the benefit of its own combination.

Finally, why hasn't this problem, pertaining to service-sector firms that engage independent contractors, previously arisen? While I can provide no definitive answer, a kind of 'shadow' of the labor exemption may furnish a clue. When almost all firms engaged service-providers on an employee basis, the labor exemption and firm exemption largely overlapped. The firm exemption authorized the firms' price coordination of the service commodity sold in the consumer market and the labor exemption authorized the serviceproviders' price coordination in the labor market, through the right to engage in collective bargaining. On a deeper normative level, the labor exemption also helped to justify the operation of the firm exemption, by providing the consistency in the application of price-fixing norms that I've discussed here. The labor exemption, at least to the extent that it was effective, helped to ensure the distribution of benefits from coordination by the firm. When more and more service-sector firms began engaging services on an independent contractor basis, those firms were able to retain the benefit from the nonenforcement of price-fixing norms as to the sale of those services in their consumer markets, while now also benefitting from the enforcement of pricefixing norms as to the purchase of those services in their supplier markets (formerly their labor markets). When Uber came along, it purified and heightened a tension in the application of price-fixing norms that already existed in any firm that sold services and engaged individual serviceproviders outside the employment relationship. By recasting itself as a market mediator that does not buy and re-sell the service of drivers, it shed even the shadow of the labor exemption that may have been protecting such firms' price coordination, even as the primary intended beneficiaries of the labor exemption were excluded from sharing in any of its benefits.

There is simply no good reason to allow the owners of a firm to benefit from a price premium from coordination when the providers of the service sold are barred from doing so. Such service providers ought to be able to engage in collective action, including coordinating directly on the prices of their services or other elements of their bargains with the firm. This conclusion does not rely upon or flow from an independent normative judgment about the value of such collective action, but simply from a consistent application of price-fixing norms themselves.

\section{CONCLUSION}

To recap, Uber has a potential antitrust problem for three reasons: 1) According to Uber itself, Uber drivers sell services but are not employees; 2) Uber coordinates and sets prices for those services, sold by Uber drivers; and 3) Uber holds itself out not as a seller of ride services, but as the seller of an app that facilitates coordination between drivers and riders. If any of these 
three factors were absent, the looming threat of antitrust liability would evaporate. Each of them also highlights certain aspects of the underlying regulatory tension that the Uber case heightens and dramatizes.

Reason (1) shows that the question of Uber's -a firm's- antitrust liability is logically connected with a question of labor and employment law: whether Uber drivers are employees. Uber drivers' putative independent contractor status also renders inapplicable the labor exemption to antitrust law - the doctrine that authorizes the price-setting activity of Uber's closest functional analogue: the hiring hall. Finally, under the conventional interpretation of antitrust law, it prevents Uber drivers themselves from engaging in price coordination, which is one half of the regulatory inconsistency that demands correction. The City of Seattle lawsuit brings the application of the pricefixing rule to Uber drivers to life, seeking to prevent a local ordinance that would correct that regulatory inconsistency by granting collective action rights to Uber drivers.

Reason (2) is a fact that is essential to Uber's business model: coordination of a market, both physical and economic, is its very reason for existence. Uber is vigorously fighting the Kalanick lawsuit for this reason. If Uber ceased setting prices, its prospects of economic viability seem likely to evaporate. In fact, the rapid information flow between buyers and sellers that is enabled by the app, absent any ability to coordinate prices, would likely drive prices below a tenable level.

Finally, Reason (3) is the feature that sets Uber apart from other firms as far as its price-coordination activity is concerned. By delinking its price coordination from the commodity it is selling, Uber pushes beyond the previously tested bounds of the firm exemption to antitrust law; the simple fact that it is a firm and firms are permitted to set prices cannot automatically be presumed to immunize it. By pushing the bounds of the firm exemption, Uber forces us to, first of all, name this largely unstated axiom of antitrust regulation; and second, to ask the normative question what its proper bounds ought to be. Once we find ourselves querying the proper bounds of the firm exemption, however, we are led to question whether the regulatory inconsistency as between the collective action of workers and the collective action of owners/investors does not in fact extend beyond Uber, to other sorts of firms whose price-coordination has until now fallen within the conventionally accepted bounds of the firm exemption. In particular, servicesector firms that engage the providers of the services they sell on an independent contractor rather than an employee basis seem to benefit from the same regulatory asymmetry as Uber.

The argument herein takes no position on the question whether Uber is legally the employer of Uber drivers. What it seeks to establish is that Uber drivers ought to have the right to engage in collective action and collective bargaining whether or not Uber is their employer, as long as Uber is 
permitted to continue to coordinate prices. Suppose that Uber is legally the employer of Uber drivers. If so, Uber drivers have the right to engage in collective action under the current law and practice of the labor exemption, as we already know, and the regulatory inconsistency I have identified evaporates. The point of this paper is that even if Uber is not legally the employer of Uber drivers, Uber drivers ought to be permitted to engage in price coordination so long as Uber is permitted to set prices. ${ }^{84}$ The same holds true for any service-provider who is not an employee, if a firm is permitted to set prices for the service she or he provides.

84. Of course, the inconsistency might also be resolved by eliminating all price coordination in such settings, which would embrace the radical implications of the plaintiff's theory in Kalanick. See supra p. 12-13. However, because Uber as well as existing service-sector firms that engage independent contractors would become essentially untenable without the ability to set prices, the most logical resolution of the tension is to permit, at least barring unusual circumstances, price coordination by individual workers or micro-enterprises. In other words, while both the implications of the plaintiff's theory in Kalanick and of the defendant's position in City of Seattle would resolve the tension, the latter is a great deal more practical. That said, a fuller defense of the "more coordination" solution to the inconsistency, over the "less coordination" solution, is beyond the scope of this paper and will be explored in future work. 
